\title{
14
}

\section{The Personal Debt Industry: Racist Debt Practices and Pasifika Peoples in New Zealand}

Bruce Curtis and Cate Curtis

This chapter is based on an analysis of the working poor as flawed consumers. We begin by recognising the generalised and the local/racialised aspects of this concept:

[The] poor of a consumer society are socially defined, and selfdefined, first and foremost as blemished, defective, faulty and deficient - in other words, inadequate - consumers.

(Bauman, 1998, p. 38)

In Pacific families, in particular, we notice that a number of the mums come in carrying other people's debt. I don't think they do it by choice, they have to, there is an expectation and that's so ingrained that there is no choice...

(Anglican Trust for Women and Children staff member, cited in Families Commission, 2012, p. 15)

In mid-2014 we were fortunate to spend time in the UK, France, the Netherlands, Portugal and Spain as part of research and study leave that was sponsored by our respective universities. ${ }^{1}$ During this time, while we enjoyed the privilege of a fully funded sabbatical and worked on our writing projects, including racist debt practices and Pasifika peoples in New Zealand, we were challenged by manifestations of what Bauman has called "flawed consumers". Almost at every corner and certainly in the safest, stereotypical holiday destinations we were confronted by homelessness and begging. Fortunately the happy snaps that we posted on Facebook excise the ammonia tang of urine from a lumpen proletariat living cheek by jowl with transnational tourists. The point here, 
of course, is that this proximity now occurs in the heart of empire. For us, at least, the beggar in Lyons, whose wares were suppurating wounds, seemed surreal. Regardless, we were forced to acknowledge both our privilege and that - despite New Zealand's 30-year track record as a neoliberal experiment (Kelsey, 1995, 1999) - we had lived sheltered lives after all.

This experience both reinforced and problematised Bauman's flawed consumers. The issue wasn't so much the very dramatic, individualised and embodied flawed consumers as beggars or rough sleepers in the context of austerity, but the all-pervasive, normalised business of "easy loans", "rapid loans", "pay-day loans" aimed at the cash-strapped employed or beneficiaries looking to avoid the humiliation of poverty. It underscored the power of the argument that the poor are pathologised and victimised in contemporary, consumer society. It certainly reinforced our notion that the poor have good reason to borrow, to go into short- and long-term debt to avoid the humiliation of inadequate consumption. But this business element of flawed consumption the predation on flawed consumers, if you like - somewhat transforms Bauman's insights from primarily a political economy into a statement about handling spoilt identity in consumer society. After Erving Goffman, accruing credit/debt (the two can always be flipped in any discussion) constitutes a means of avoiding stigma. The poor borrow to hide their spoilt identities as consumers, even if, and perhaps because, there is little chance of repaying the principal. The poor borrow to pass as proper consumers (Goffman, 1963).

In more practical terms, the sabbatical allowed us to better contextualise racist debt practices and Pasifika peoples in New Zealand. This means an appreciation of the Global Financial Crisis and how it has played out in neocolonial New Zealand - specifically its racist consequences, but also what this victimisation normalises more generally.

\section{New Zealand is a debtor economy}

As a settler colony of the UK, New Zealand has been a debtor economy for much of its history (the country gained formal independence in 1908). However, in recent decades the impacts of debt, and of indebtedness, have been obscured by a neoliberal rhetoric and by its very uneven effects. New Zealand was one of the first movers in the international adoption of neoliberal policies in the latter part of the 20th century and arguably it moved the furthest, at least among the OECD nations. ${ }^{2}$ 
This chapter will draw particular attention to the racialised aspects of debt, but we do first wish to contextualise debt in terms of the broader economy. One measure of debt is the current account, which measures the balance of trade between imports and exports. New Zealand's current account has been in debt since 1973 and, apart from periods of worldwide prosperity (the "Long Boom") and of war (when New Zealand's exports of food and fibre were needed urgently by the UK), this is the normal state of affairs. Like almost all colonies, even those like New Zealand that enjoyed a somewhat privileged position thanks to its close historical ties to the motherland (i.e. based on colonisation by British settlers), New Zealand lacks a balanced economy. Exports including agricultural produce, tourism and commercialised education are the "core" of the economy. Manufacturing and domestic focused sectors have always occupied a somewhat parlous position and were more or less obliterated in the mid-1980s when successive New Zealand governments embraced neoliberal or "more market" policies. The country had abandoned most tariffs, import quotas and domestic subsidies by the early 1990s to secure the nation as a "free and open trading economy". Neoliberal policies did not much, if at all, improve the state of the current account. Indeed, while the champions of neoliberalism often claim that the economy is healthier with a more market approach, they pay scant regard to the individuals and communities that make up that economy.

There isn't room here to document the many failings of neoliberalism other than to note the following: (1) the sale of state-owned assets to the private sector and user pays has resulted not in a more open and efficient system of delivering services but in a range of monopolies or cartels that are primarily owned by foreign investors (e.g. telecommunications, banking, infrastructure and, increasingly, health); (2) neoliberal policies have locked in a low-wage scenario - by all measures the standard of living for the majority of New Zealanders has fallen with the neoliberal orientation; (3) New Zealand is a far less egalitarian society the difference between rich and poor has widened significantly. These and other failings paint a gloomy picture and in terms of personal debt the situation is even worse. Indeed, the New Zealand "experiment" with neoliberalism has created the perfect storm for a racialised indebtedness.

First, and most obviously, the low-wage scenario coupled with the decimation of manufacturing and a host of semiskilled jobs since the 1980s means that average wages or social welfare are simply inadequate to meet the needs of individuals and families. Indeed the average working family in New Zealand can only just get by with the aid of Working for 
Families, a tax credit scheme (see below). This scheme, more than anything, supports low wages and low-wage-paying employers rather than struggling families. Second, New Zealand has a high level of external debt (approximately $126 \%$ of GDP) and a relatively low level of public (state) debt (approximately 39\% of GDP). This debt is private (owed mainly by individuals to transnational banks) rather than public. High external debt combined with low state debt reflects New Zealand's early adoption of neoliberalism - what is now called "austerity". Yet the international ratings agencies regard New Zealand very highly. For example, Moody's rates New Zealand in the top flight of current ratings (Aaa). Clearly the capacity of the "rule of law" to secure the servicing of debt is more important to international creditors than the (poor) health of the economy (and by inference, of the people who make up that economy). The result is that debt is at every level a private issue despite the fact that neoliberal policies create this situation with low wages and a high interest policy, and transnational banks that have cornered the market on mortgages for otherwise unaffordable homes. Third, debt call it the credit industry - is big business and has been unfettered by neoliberalism.

Thus low wages combined with an increasing cost of living have led to increased personal indebtedness, the rise of a burgeoning credit industry and the all-encompassing nature of personal debt (Families and Retirement Commissions, 2008). Legge and Heynes (2009) favour a locus of control argument in terms of taking on debt. However, this seems doubly blind: blind to the issues of social structure in general and to the specifics of personal debt. In the context of a low-wage economy, declining measures of "affordability" and the necessity of (easy) credit, this appears little more than blaming the victims. At the same time, recent decades have seen a proliferation of private finance companies that target the most vulnerable in society. While it is unfair to portray New Zealand's "psychology" in terms of a rehashing of Livingstone and Lunt (1992), a rounded social psychology perspective is definitely lacking (Walker, 2013).

\section{Pasifika peoples and debt}

The term Pasifika, or Pasifika peoples, is a collective label that is applied to locally born and migrant people from the nations of the Pacific: Samoa, Fiji, Tonga and Niue, among others. The term has replaced others, in official reporting at least, that are now regarded as offensive or old-fashioned (Pacific Islanders and Polynesians are examples 
of the latter). The re-emergence of the German-inflected spelling of Pasifika (Germany was a major colonial force in the Pacific prior to the First World War) reflects the open-ended and contested nature of postcolonial efforts at terminology. ${ }^{3}$ While the terminology is problematic, the social statistics that it reveals is a straightforward story of structural, racist disadvantage.

Pasifika peoples constitute around $7 \%$ of the population of New Zealand. The measurement of ethnicity in New Zealand is a somewhat contentious issue because in official surveys and most others, individuals can self-select multiple identities which when totalled exceed the number of individuals surveyed. This double-counting appears to be most significant for those selecting Māori as part of their ethnic identity. Bearing this in mind, the last census figures indicate that alongside the $7 \%$ Pasifika, $71 \%$ of the population identified with an European ethnicity, $15 \%$ with Māori and $12 \%$ with Asian (Statistics New Zealand, 2013a). The Pasifika population is the youngest (by median age), the shortestlived and the most fertile of the four main ethnic groupings (Curtis and Curtis, 2006).

They are also disproportionately located in Auckland (New Zealand's somewhat sprawling and largest conurbation), especially in its poorest, southern suburbs; located and overcrowded, it should be noted. Pasifika households are the most likely to have insufficient bedrooms: " $43 \%$ of Pasifika people live in households requiring an extra bedroom, compared to $23 \%$ of Māori and $4 \%$ of European households" (Henare et al., 2011 , p. 34). This overcrowding and the damage that it causes are long documented. For instance, using data drawn from the late 1990s, in a number of presentations in 2003, Chris Bullen from the Clinical Trials Research Unit at the University of Auckland demonstrated a spatial overlap of overcrowding and meningococcal disease cases that was breathtaking in its correlation. Yet rather than spend (what was then a very considerable budget surplus) on social housing to the lasting benefit of the residents of South Auckland, the neoliberal, Labour government of the day preferred to waste several millions of dollars on a botched vaccination campaign, the end result of which was an increased mortality rate from the disease (see Law and Sumner Burstyn, 2006). ${ }^{4}$ In these suburbs, poor living conditions and poor nutrition have resulted in increases in illnesses that had been considered third-world problems, such as rheumatic fever, childhood pneumonia and tuberculosis, as well as meningococcal disease, mentioned above (Baker et al., 2003).

Other socioeconomic statistics are equally grim, but they are often hard to locate or are hidden away in the text of official reports, so we 
will simply run through a recent selection of them. Pasifika peoples have the smallest share of family net worth. Thus,

Families containing at least one person of Pacific ethnicity had the lowest overall family net worth of all the ethnic groups analysed. Very few families had a level of family net worth that put them in the top family net worth quintile, and 86 percent of Pacific ethnicity one-parent families were in the bottom quintile.

(Statistics New Zealand, 2008, p. 13)

Pasifika workers are the

lowest-paid ethnic group with an average wage last year [2013] of $\$ 20.59$ an hour, behind Māori on $\$ 22.45$, Asians on $\$ 23.49$ and Europeans on $\$ 27.08$. That wage gap has hardly changed in a decade. Pacific workers averaged 25 per cent below Europeans in 2004 and 24 per cent below Europeans today.

(Collins, 2014)

Interestingly, Pasifika people are not particularly over-represented in the main benefits (income support payments) that are available to the working-age population. In June 2014 they represented around $7.8 \%$ of beneficiaries - roughly in line with their population share (Statistics New Zealand, 2014). When income from all sources (e.g. including social welfare benefits) is considered, Pasifika peoples on average receive $65.94 \%$ of the total average income compared with the $80.19 \%$ that Māori receive and the $107.59 \%$ that the average European receives (Statistics New Zealand, 2013b).

A recent Salvation Army report confirms that this Pasifika "share" of working-age benefits has hovered around population levels, although labour force participation was worsening: "In December 2008, the Pacific labour force participation rate was $67 \%$ against a nationwide participation rate of $69.6 \%$. In March 2014, the Pacific participation rate had fallen to just above $62 \%$, while the national rate had climbed back to $69.6 \%$ following a decline to $67.5 \%$ during the recession" (Tanielu and Johnson, 2014, p. 23). Unsurprisingly, Pasifika families are the most indebted:

For single families, while mortgage debt-asset ratios are broadly comparable (all less than 50 percent), single Māori, Pacific and other families have high non-mortgage debt-asset ratios. The median single 
Pacific family, in particular, appears to hold twice as much nonmortgage debt as assets. This suggests they have very low or negative net worth...

(Families Commission and Retirement

Commission, 2008, p.16)

It certainly isn't our intention to add to the stereotypical and racist framings of any ethnicities or to reinscribe essentialist readings, but the socioeconomic statistics suggest that the deprivation that is experienced by Pasifika peoples owes much to that endured by the working poor more generally. We contrast this deprivation, with some trepidation, with accounts from across the political spectrum that emphasise Māoritanga, racism and welfare dependency in New Zealand. We argue that Pasifika peoples, as working poor, have a particular vulnerability to the practices of racialised debt. We argue that because Pasifika people are working poor, hegemonic accounts will emphasise racism by way of explanation. In respect of the former claim, we agree with the main findings of the Families Commission (2012) in Pacific Families and Problem Debt and are indebted to that scholarly investigation.

The multiple authors of Pacific Families and Problem Debt ${ }^{5}$ identify a range of causes for indebtedness from which we extrapolate. We will discuss these next but must first mention racism, which they are somewhat coy about. The disadvantaged position of Pasifika peoples in New Zealand, and their overwhelming status as working poor, constantly in the shadow of the reserve army of labour, is an expression of racism. New Zealand racism is mediated by its settler colonial origins and the displacement of Mãori tribal society from the best lands by British capital and migrants. Pasifika peoples are migrants too, encouraged to New Zealand in the boom times of the 1950s and 1960s to fill a range of blue-collar jobs. In this respect, Pasifika benefited from the colonial networks of the British Commonwealth, which facilitated migration to New Zealand (Macpherson, 2004). However, this migration was sharply proscribed by its occupational and locational boundaries. When the "Long Boom" ended and decades of stagnation morphed into an outright, neoliberal attack on working people in the mid-1980s, Pasifika blue-collar workers were hit perhaps hardest of any ethnic grouping.

In the context of an attack - a sustained attack - on the pay and conditions of working people, and increasingly of beneficiaries, it would be hard to imagine the racially victimised Pasifika peoples not having 
recourse to personal debt. And it would be wrong-headed to invert an explanation for indebtedness in terms of Pasifika cultural practices. These practices are significant, however, and include three main, interlinked, analytical elements:

1. The enduring significance of kinship networks A stereotype of Pasifika peoples is that they are more family-centred than their Palagi (European) neighbours. The continued importance of kinship networks is undoubted and informs not just the social life of Pasifika peoples but also almost all academic work and policy initiatives in the area. Multigenerational housing is an obvious expression, and overcrowding is its down-side. Kinship networks are frequently transnational, in terms of both migration to New Zealand (Macpherson, 2004) and familial exchanges, but also remittances. An unknown number of Pasifika families remit money to their senior male relatives in their initial homeland:

They are principally used, at least initially, to repay debts, to finance migration of kin, and to purchase consumer goods including housing. They often reinforce a traditional set of values that emphasizes the prevailing social hierarchy and strengthens established social organization. Remittances tend to go to senior family members who use them in traditional ways instead of for structural changes such as land tenure reform.

(Connell and Brown, 2005, pp. 10-11)

2. Continuing elements of a gift economy Kinship networks and remittances overlap with continuing elements of the gift economy, which find expression in familial obligations to major events both in New Zealand and their initial homelands (e.g. weddings, funerals, and community- and family-based celebrations). In terms of debt, kinship and the gift economy can result in some family members (it would seem predominantly mothers) holding debt for the benefit of others (e.g. in-laws, male children and husbands).

3. Relative importance of the Church The extent to which the Church is a progressive or reactionary force in Pasifika communities is hotly debated and also has great potential for racist demagoguery. The Families Commission report Pacific Families and Problem Debt (2012) goes to some trouble to discount tithing as a structural source of indebtedness, which in part reflects the role of Church-based groups in providing community support. We regard the relative importance of the Church, in 
combination with kinship and gifting, as significant in securing a trope of respectability in Pasifika communities. By respectability we mean a heightened aversion to the stigma of flawed consumerism (to combine Goffman's and Bauman's imagery).

In summary, we posit that Pasifika peoples are poor, subject to structural racism and over-represented in terms of being working poor, and that these socioeconomic realities are mediated by a culture (or subculture) of respectability and stoicism.

\section{Thank you, Instant Finance}

All writing has a start-point, and for us it was a series of staggeringly racist advertisements from the loan company Instant Finance, beginning in 2011. These appeared on TV and radio, in print, on billboards and online. They were tailored for the Pasifika community and featured a high-profile Mãori sportsman, Stacey Jones (former captain of the New Zealand Rugby League team). ${ }^{6}$ The advertisements emphasised stereotypical/racist portrayals of Pasifika peoples: happy, smiling and naïve; needing easy money for a holiday, a daughter's wedding or to fix up the old banger of a car. The tag line "Thank you Instant Finance" was spoken by a motherly Samoan in stereotypically accented migrant English. We were not alone in being offended. Members of the public made complaints to the Advertising Standards Authority about several loan companies in 2011-2012, including at least five against Instant Finance. The minority that were upheld were on the grounds of non-disclosure of required information rather than targeting the poor and vulnerable (Edmunds, 2012).

This is hardly surprising. Recent years have seen the proliferation of companies that offer unsecured loans at high rates, and often in a misleading fashion. They include Cash Train, offering a NZD 750 loan for ten days at a cost of NZD 128. This includes a one-off administration fee of NZD 53, and interest at NZD 1 per NZD 100 borrowed per day or $365 \%$ per annum (http://www.cashtrain.co.nz/). Payday Loans has advertised rates "as low as 1.38 per cent a day" - equivalent to $503 \%$ per annum - while stating that "Pay Day Loans can be a great financial tool to help get you through to your pay day - and can even help save you time and money on things such as bank fees or penalties on bills" (http://www.pay-day-loans.net.nz/). Save My Bacon charges an even higher rate of $547.5 \%$ per year. This is explained thus: "But this term is an annualised measure that wasn't devised with Save My Bacon small and urgent loans in mind... Our loans only have a maximum term 
of 31 days and we do not offer a long-term loan product for a year" (https://www.savemybacon.co.nz/charges). Simple Cash (https://www .simplecash.co.nz) offers a similar explanation, with interest rates of up to $803 \%$ per annum.

Several loan companies target Pasifika people through the images that they use, such as Pasifika families attending a wedding. The recent research by the Families Commission (2012) noted that many of the participants commented on tailored advertising strategies, including advertisements on Pasifika-targeted radio stations in Pacific languages. Many Pasifika-focused advertisements explicitly target people with poor credit histories. For example, the Aqua Cars \& Finance advertising and website states: "We provide vehicle finance for almost anyone... Even if you think your credit's a bit dented - think again! With Aqua car finance, you could still get a loan for the car you need. It's quick, and it's easy to put yourself in the driver's seat!" (http://www.aquacars.co.nz/).

Our unscientific review of Auckland-based finance companies appears to confirm deliberate targeting. The websites of those based in south Auckland tend to be more informal, suggest that a poor credit history need not be a concern and that loans can be approved quickly, and have a larger number of casually dressed Pasifika, Māori and Asian people in their images. In contrast, companies based in the central business district tend to use more white people and more formal language, and also to advertise investment opportunities.

Perhaps an even greater problem than the ease with which credit can be obtained from finance companies is the increase in "mobile truck shops". These trucks frequent deprived neighbourhoods and sell everything from basic grocery items to lounge suites, on credit and often at high prices. Anecdotal evidence (quoted by Grunwell, 2009) suggests that they often charge three or four times the normal retail price. Some request that consumers complete several automatic payment forms, supposedly so that if one is cancelled by the consumer it can easily be replaced by the company (Waiapu Anglican Social Services, 2010).

\section{Pasifika peoples, flawed consumers and hegemony}

Bauman's work on flawed consumers has evolved into a broader discussion of "liquid fear" - the notion that contemporary capitalism is marked by amorphous fears and anxieties. These fears are reified in hegemonic accounts for precisely the same reasons that were long ago identified by Gramsci and the Frankfurt School: to obscure the structural contradictions of capitalism; to destroy class solidarity by stigmatising 
and scapegoating some fraction of the working class; and to foster false consciousness. In this respect, Pasifika people are the perfect "fall guys". Without racist accounts, indebtedness among Pasifika peoples might be understood in terms that would foster working-class solidarity. The notions that they are working poor, family-centred and respectable just like other working people might in themselves be stereotypes, but they are ones that invite comparison and inclusion. Racist formulations provide the opposite dynamic, simultaneously empowering a form of vulture capitalism which predates precisely on the working poor while inviting explanations that are based on difference and exceptionality.

\section{Respect and deprivation}

The desire for respectability - to conceal one's status as a flawed consumer - coupled with a lack of access to resources can only exacerbate the effects of problem debt. Debt has been linked to a variety of mental and physical health problems (Balmer et al., 2006). It can significantly change how people live their lives, induce feelings of uncertainty about what is going to happen next, and engender feelings of stigma and shame. The more debts people have, the more likely they are to have poor mental health, with estimates that niearly half of all adults with debt have a mental disorder (Fitch et al., 2010).

Debt may also have indirect psychological effects on the household as well as those who are directly responsible for managing money. The psychological wellbeing of children may be impacted by parental stress and depression, and result in conflict-based family relationships and potential mental health problems among other family members (Fitch et al., 2010). Debt is also linked to higher rates of domestic violence and relationship breakdown (Balmer et al., 2006).

In addition to the somewhat distal impacts of poverty on physical health mentioned above, such as those related to overcrowding, a range of more immediate impacts occur. Insufficient financial resources may mean that a trip to the doctor is missed in favour of paying rent, and that food choices are made on the basis of cost and how "filling" an item is rather than its nutritional value. Cheer et al. (2002) note that food spending is often the easiest cut to make for those who are living in debt; it is not a fixed expense and non-payment does not result in the repossession of goods. As discussed above, due to a high value being placed on collective responsibility and relatively high religiosity, individual and household needs may take a low priority. In practical terms, such commitments can lead to a lack of food in the ensuing 
weeks, as shown in these quotes from the work of Cheer et al. (2002, p. 510):

Our cultural obligations are more important than food and so when something comes up like that then it will be just bread and jam that we eat. Food comes after cultural donation. It's also more important than bills like the power... Every time there is a...function, we are asked to pay. There was only just a wedding and funeral we had to pay for in the same week. Even when the family function is back in Samoa, we still have to donate.

The kids have gone to school without lunch. I've gotten letters from the school about it asking that I give them lunch every day. The guilt is huge.

These quotes indicate the tensions involved in maintaining respectability while living in poverty, and emphasise the attractiveness of obtaining credit/debt to attempt to address deprivation. In this regard, indebtedness is the last recourse of the respectable, working poor under neoliberalism. We believe it to be a common, potentially unifying experience for working people. For Pasifika peoples it may involve challenging the centrality of the Church and of respectability in favour of foregrounding the dilemmas of being working poor and of confronting racism.

\section{Breaking the debt cycle}

Possibilities for reducing debt, and the underlying issues of vulnerability and inequality, may be targeted at the macro- and community (and individual) levels. The Families Commission (2012) offers a range of actions that are aimed specifically at Pasifika families, though many are more broadly applicable. These include financial literacy education (also see Reed and Sutton, 2012); social skills training, including budgeting and communication; intensive case management; advocacy with agencies; and engagement with community leaders and churches. Calls for financial literacy training and coordination across services have been common since the global financial crisis, both in New Zealand and internationally (see e.g. Balmer et al., 2006; Fitch et al., 2010). Some other suggestions for managing debt rely very simply on managing psychological factors within families:

A better understanding of the interplay between factors in a family decision-making setting is also required. For example, where in a 
two-parent family one partner has an internal locus of control and the other an external one, it may be in the family's long-term interests for each to be aware of their tendencies, strengths and weaknesses and to empower the internally focused partner to make decisions about the family's finances.

(Legge and Heynes, 2009, p. 40)

However, it seems unlikely that such an approach will assist the increasing numbers who simply have insufficient money about which to make decisions, even if it were possible to ignore or overcome other factors that come into play within families and from their social contexts. Similarly, as noted by Balmer et al. (2006), improving access to financial and budgeting advice may help people to deal with acute financial crises but it will not change the underlying drivers of poverty and social exclusion. Additionally, disadvantaged groups are likely to experience difficulties (further inequalities) in accessing services, serving to further exacerbate their social and economic marginalisation.

The start-point for addressing racist debt practices in New Zealand undoubtedly lies in small reforms around budgetary advice and access to credit/debt. However, while these policies and programmes may assist some individuals and families, they will at best treat the symptoms resulting from underlying structural issues. At worst they support and perpetuate a "blame the victim" mentality, and reinforce stereotypes. By providing an opportunity to claim that assistance is being afforded, they offer an avenue for government to ignore and obfuscate the drivers of debt and inequality, thus continuing the construction of debtors as a group of careless and/or ignorant individuals. Addressing debt must transcend this sort of small " $\mathrm{r}$ " reform if it is to succeed. The endpoint of such initiatives lies in the realm of political economy, in addressing the "neoliberal" attacks on Pasifika peoples and on all working people.

On a fundamental social level, many potential solutions revolve around political change. These include policies around the minimum wage; capping of interest rates and loan fees; further simplification of loan documents; the empowerment of unions, incorporating the reversal of the policies of recent decades which have rendered them all but powerless; a return to progressive taxation, including the removal of Goods and Service Tax (the equivalent of Value Added Tax); the reversal of austerity policies; and the return of tariff and import restrictions to encourage local production beyond dairying. 
A combination of developing and evaluating social service programmes, while simultaneously challenging the structural contradictions of capitalism, addressing false consciousness and promoting empowerment, is precisely the raison d'être of $\mathrm{CP}$.

\section{The potential of community psychology approaches}

$\mathrm{CP}$ is an applied social science that attempts to enhance the life circumstances of groups of people, especially those who are oppressed, stigmatised or otherwise marginalised. Practitioners favour group, community and societal interventions which address the structural factors that maintain oppression and suboptimal health, recognising the limitations and potentially victim-blaming nature of individually focused interventions. The way in which $\mathrm{CP}$ has developed in New Zealand owes much to our history, in particular as it pertains to issues of culture, ethnicity and colonisation (Robertson and Masters-Awatere, 2007).

$\mathrm{CP}$, politics and culture In order to discuss the practice of $\mathrm{CP}$, and in particular its approach to culture and inequality, it is necessary to first describe something of local psychology's past and the context in which it arose. Of specific relevance is the history of racism.

Colonisation proceeded in New Zealand in a similar way to other parts of the world. From settlement, the colonial administration governed New Zealand largely as if it had absolute sovereignty. For example, the 1852 Constitution Act established a franchise based on land held in individual title, effectively denying the vote to almost all Māori, for whom land was held collectively.

The last part of the 19th century saw the emergence of a more socially just tradition, albeit it one that focused on the needs of the (largely) British settlers. From the 1890 s to the 1910 s, successive Liberal Party governments laid down the basis of the welfare state (King, 2003, cited by Robertson and Masters-Awatere, 2007). By the late 19th century, New Zealand had gained a reputation as the "social laboratory of the world". Women gained the vote in 1893 (the first country in the world to enfranchise women); and labour laws that improved conditions for workers were introduced, as was an old-age pension. The government built houses to be rented to workers at affordable rates, and there were significant advancements in public health. The cornerstone of the first Labour government was the 1938 enactment of the Social Security Act, providing assistance "from the cradle to the grave" - a comprehensive package of measures including healthcare, increased access to pensions and 
social welf are benefits. However, these benefits were not evenly applied. For example, the 1938 act allowed for the payment of benefits at a lower rate "if the maximum benefit is not necessary for the maintenance of the beneficiary". Communal living arrangements were often cited as a reason, but there is evidence of the widespread and unjustifiable practice of reducing the benefits paid to Māori (Baker, 2012).

By the mid-20th century, tensions related to the urbanisation of Māori meant that "race relations" were on the social and political agenda. Previously Māori largely lived in rural settlements, but post-war prosperity led to increased demand for labour in towns and cities. At this time, "race relations" meant a focus on maintaining cordial relationships rather than cultural justice. Rapid changes to the make-up of the New Zealand population were to follow. By the early 1970s, the proportion of New Zealand's foreign-born population who were from countries outside the white British Commonwealth was 30\% - twice that of 20 years earlier. As the composition of the population changed, so did attitudes. Civil rights crusades in the USA, independence movements in some British colonies and a renaissance in Māori culture brought social issues to the fore, especially among some psychologists.

Alongside a changing population and changing attitudes came, from the mid-1980s, major changes to social and economic policy. The country had the biggest rise in inequality in OECD member nations in the two decades beginning in the mid-1980s, taking New Zealand from well under the OECD average to well above it (Ministry of Social Development, 2013). A number of measures of social capital indicated a steady decline from this period. For example, the youth suicide rate grew sharply into one of the highest in the developed world (reported by the Ministry of Health; see Curtis and Curtis (2011) for a broader discussion); the number of New Zealanders estimated to be living in poverty grew by at least 35\% between 1989 and 1992 (Kelsey, 1999); crime (Ewing, 2001) and the number of food banks (Ballard, 2003) increased dramatically; and the public health system was particularly negatively impacted, leading to a significant deterioration in health standards among not only working- but also middle-class people, as services were rationalised (Bramhall, 2003). The poverty rate for working-age adults living on their own trebled from 1984 (10\%) to 2007 (30\%) (Ministry of Social Development, 2013).

With this history it is perhaps unsurprising that $\mathrm{CP}$ developed in response to the concern of many psychologists that preventing social problems and enhancing the quality of people's lives requires more than behavioural interventions at an individual level. It requires the 
thorough interrogation of, and intervention in, the broader social and political systems that influence human behaviour, in turn confronting oppression in all forms, including sexism, racism and classism, and addressing the resultant disparities (Department of Psychology, University of Waikato, 2011). Though CP in New Zealand dates from the 1980s, its underpinnings can be found decades earlier.

The notion that psychology in general should not be a culture-free endeavour was embedded in some of the writings of early New Zealand psychologists. Of particular note is the work of Ernest Beaglehole (1906-1965). He was influenced by the founders of psychological anthropology, including Ruth Benedict, Margaret Mead and Edward Sapir, and he published many studies of Pacific Island and Māori communities. His contribution is perhaps most evident in Mental Health in New Zealand (1950). In discussing the issues that underlie psychological problems, he emphasised situational factors and emotional stressors, including "strained personal, social and economic conditions, together with unsuitable or unsatisfactory employment" (p. 47). He argued that good health required participation in social networks, feelings of security and connectedness, and being part of a cooperative common life, as well as the fulfilment of practical needs such as good-quality housing. Beaglehole drew a connection between culture and mental health, citing aggressive competition and consumerism as being implicated in mental illness (Robertson and Masters-Awatere, 2007).

CP praxis As is the case elsewhere in the world, since its inception, CP in New Zealand has taken a clear stance in relation to values. In particular, the notion of value-free science is rejected. Instead, values such as social justice, collaboration, diversity and empowerment are emphasised. There is a particular importance placed on the critical analysis of hegemonic practices. As might be expected given its antecedents in cross-cultural and ethnopsychology, CP here has focused particularly on culture and especially institutionalised racism.

Today, CP practitioners can be found in a range of sectors, including health services and promotion, social and welfare services, education, community development, disability services, housing, child protection and addiction. They are employed by government at all levels, by iwi (tribal) organisations, by NGOs and by research companies (Robertson and Masters-Awatere, 2007), and they are well positioned to address issues of indebtedness.

That debt may be both a form of poverty and a way of dealing with poverty makes it a complex topic to deal with. However, $C P$ as an 
academic discipline has long employed a critique of capitalist hegemony and its impacts on specific groups, especially cultural groups. That critique must include the role of austerity politics in the current entrenchment of racialised debt practices.

\section{Conclusion}

New Zealand has been in debt for some decades. Since the adoption of austerity measures in the 1980s, income has decreased while debt has increased. The country had the biggest rise in inequality in OECD member nations in the two decades following the mid-1980s, taking it from well under the OECD average to well above (Ministry of Social Development, 2013). Although many New Zealanders are experiencing significant debt as a result, some groups are more vulnerable than others. We have argued that Pasifika peoples are at particular risk. Whereas much of the New Zealand population is in debt due to high mortgages, Pacific Island families are often borrowing to cover their basic needs loans to be able to buy groceries and pay for utilities. This is due to a number of sociocultural factors, but also the pernicious behaviour of the credit industry, which targets Pasifika people precisely because they are respectable exemplars of the working poor. In the face of this double burden, or racism and capitalist hegemony, we conclude that the possibilities for justice, fairness and wellbeing require significant economic and political change. In the first instance a response to this crisis of racialised personal and community indebtedness must call forth a response to austerity policies.

\section{Notes}

1. This article was also assisted by a grant to Bruce Curtis from the Europe Institute, at the University of Auckland. I am deeply indebted to the Europe Institute for their support of a project that began examining exhortations to politeness in the public sphere and has been expressed here, in part, as an examination of damaged identities.

2. New Zealand was an early adopter of neoliberal policies. This was in part because of the right-wing rhetoric of market efficiencies, monetarism and private- over public-good arguments. This transformation of policy included (1) floating the exchange rate; (2) scrapping import controls and tariffs, and subsidies to domestic manufacturing and farming; (3) selling of state-owned assets (e.g. telecommunications, banking and railways); (4) enforcing the sale by local authorities of airports, harbours, power generation and supply, and other revenue streams; (5) requiring the survival of state-owned enterprises to return a dividend to the state (e.g. postal services, public broadcasting); (6) 
deregulating the banking, finance, power, telecommunications infrastructure supply and export agriculture sectors; (7) cutting unemployment and disability benefits; (8) raising the age for pensions; (9) abolishing the legal status of trade unions; and (10) drastically limiting the state's capacity to borrow to fund any fiscal interventions (Curtis, 2001).

3. We use the same definition of Pacific people that is commonly used in New Zealand government reports and by the Ministry of Māori and Pacific Island Affairs: people who claim ethnic links to the island nations of the Pacific.

4. It is unclear whether this public health debacle for Pasifika peoples counted for or against Helen Clark, the prime minister at the time and a former minister of health, in her successful campaign to run the United Nations Development Programme.

5. The Families Commission research team: Dr David Stuart, Janine Couchman, Dr Jeremy Robertson, Karen Stewart, Tofilau Kerupi Tavati, Liz Tanielu and Margaret Retter. The Ministry of Pacific Island Affairs research team: Dr Lana Perese, Dr Ieti Lima, Maiava Carmel Peteru and Analosa Ulugia-Veukiso.

6. Then Prime Minister Helen Clark stated in 2005: "He's the epitome of a New Zealand champion."

\section{References}

Baker, M. (2012). Family Welfare - Welfare, Work and Families, 1918-1945. Te Ara the Encyclopedia of New Zealand. Manatū Taonga Ministry for Culture and Heritage, updated 13 July 2012. Retrieved. http://www.teara.govt.nz/en/familywelfare/page-3.

Baker, M., Goodyear, R. and Howden-Chapman, P. (2003). Chapter 5: Household crowding and health. In Statistics New Zealand (ed.) What Is the Extent of Household Crowding in New Zealand? An Analysis of Crowding in New Zealand Households, 1986-2001. Wellington: Statistics New Zealand, 58-87.

Ballard, K. (2003). Inclusion, Exclusion, Poverty, Racism and Education: An Outline of Some Present Issues. Dunedin: University of Otago.

Balmer, N., Pleasence, P., Buck, A. and Walker, H. C. (2006). Worried sick: The experience of debt problems and their relationship with health, illness and disability. Social Policy and Society, 5, 39-51.

Bauman, Z. (1998). Work, Consumerism and the New Poor. Maidenhead: Open University Press.

Beaglehole, E. (1950). Mental Health in New Zealand. Wellington: University Press.

Bramhall, S. (2003). The New Zealand health care system. Physicians for a national health program. Retrieved. http://www.pnhp.org/news/2003/january/ the_new_zealand_heal.php.

Cheer, T., Kearns, R. and Murphy, L. (2002). Housing policy, poverty, and culture: "Discounting" decisions among Pacific peoples in Auckland, New Zealand. Environment and Planning C: Government and Policy, 20, 497-516.

Collins, S. (2014). Closing the Gaps: The Great Ethnic Job Divide, New Zealand Herald. Retrieved on July 31,2014 . http://www.nzherald.co.nz/nz/news/article .cfm?c_id=1\&objected $=11220647$.

Connell, J. and Brown, R. P. C. (2005). Remittances in the Pacific: An Overview. Philippines: Asian Development Bank. 
Curtis, B. (2001). Reforming New Zealand agriculture: The WTO way or farmer control? Intemational Joumal of Sociology of Agriculture and Food, 9(1), 29-42.

Curtis, B. and Curtis, C. (2006). The social setting. In Miller, R. (ed.). New Zealand Government and Politics (4e). Auckland: Oxford University Press, 14-24.

Curtis, C. and Curtis, B. (2011). The operation of a suicidal cohort and its socio-economic origins. In Walker, C., Johnson, K. and Cunningham, L. (eds.). Community Psychology and The Economics of Mental Health: Global Perspectives. Houndmills, UK: Palgrave MacMillan, 62-79.

Department of Psychology (2011). Community Psychology Graduate Handbook. Hamilton, NZ: Department of Psychology, University of Waikato.

Edmunds, S. (2012). Costly ads lure Kiwis to high-interest loans. New Zealand Herald. Retrieved on July 31, 2014. http://www.nzherald.co.nz/business/news/ article.cfm?c_id=3\&objectid $=10855713$.

Ewing, I. July 31, 2001). Crime in New Zealand. Wellington: Statistics New Zealand. Retrieved. http://www2.stats.govt.nz/domino/external/pasfull/ pasfull.nsf/0/4c2567ef00247c6acc256b970010b936/\$FILE/CrimeNZ.pdf.

Families Commission (2012). Pacific Families and Problem Debt, Research Report No. 6. Wellington: Families Commission.

Families Commission and Retirement Commission (2008). Beyond Reasonable Debt: A Background Report on the Indebtedness of New Zealand Families, Research Report No. 8. Retrieved on July 31, 2014. http://www.familiescommission.org .nz/web/beyond-reasonable-debt/index.html.

Fitch, C., Hamilton, S., Basset, P. and Davey, R. (2010). Debt and Mental Health: What Do We Know? What Should We Do? London: Royal College of Psychiatrists, College Research and Training Unit.

Goffman, E. (1963). Stigma: Notes on the Management of Spoiled Identity. Englewood Cliffs, NJ: Prentice-Hall.

Grunwell, R. (2009). Mobile Stores a Bad Deal. New Zealand Herald. Retrieved on July 31,2014 . http://www.nzherald.co.nz/nz/news/article.cfm?c_id=1\& objectid=10616604.

Henare, M., Puckey, A. and Nicholson, A. (2011). He Ara Hou: The Pathway Fonward. Auckland: Mira Szászy Research Centre, The University of Auckland.

Kelsey, J. (1995). The New Zealand Experiment: A World Model for Structural Adjustment? Wellington: Bridget Williams Books.

Kelsey, J. (1999). Life in the economic test tube: New Zealand "experiment" a colossal failure. Electronic Radical Joumal of Organization Theory, 2(1), 1-5.

Law, R. and Sumner Burstyn, B. (2006). Why has Meningococcal Death Rate Increased Since the Introduction of Vaccine? Scoop. Retrieved on July 31, 2014. http://www.scoop.co.nz/stories/GE0611/S00058.htm.

Legge, J. and Heynes, A. (2009). Beyond reasonable debt: A background report on the indebtedness of New Zealand families. Social Policy Joumal of New Zealand, $35,27-42$.

Livingstone, S. M. and Lunt, P. K. (1992). Predicting personal debt and debt repayment: Psychological, social and economic determinants. Journal of Economic Psychology, 13, 111-134.

Macpherson, C. (2004). From Pacific Islanders to Pacific people and beyond. In Spoonley, P., Macpherson, C. and Pearson, D. (eds.). Tangata Tangata: The Changing Ethnic Contours of New Zealand. Southbank, Victoria: Thompson, $135-156$. 
Ministry of Social Development (2013). 2013 Incomes Report: Summary and Overview. Wellington. Retrieved. http://www.msd.govt.nz/about-msd-and-our -work/publications-resources/monitoring/household-incomes/.

Robertson, N. R. and Masters-Awatere, B. (2007). Community psychology in Aotearoa/New Zealand: Me tiro whakamuri a kia hangai whakamua. In Reich, S. M., Riemer, M., Prilleltensky, I. and Montero, M. (eds.). The History and Theories of Community Psychology: An Intemational Perspective. New York: Kluwer Academic Publishers, 140-163.

Statistics New Zealand (2008). Family Net Worth in New Zealand. Wellington: Statistics New Zealand.

Statistics New Zealand (2013a). 2013 Census - Major Ethnic Groups in New Zealand, Wellington: Statistics New Zealand.

Statistics New Zealand (2013b). New Zealand Income Survey: June 2013 Quarter. Retrieved. http://www.stats.govt.nz/browse_for_stats/income-and-work/ Income/ NZIncomeSurvey_HOTPJun13qtr/Tables.aspx.

Statistics New Zealand (2014). National Level Data Tables - June 2014: Characteristics of Working-Age Recipients of Main Benefits. Retrieved on July 31, 2014. https://www.msd.govt.nz/about-msd-and-our-work/publications-resources/ statistics/benefit.

Tanielu, R. and Johnson, A. (2014). This Is Home: An Update on the State of Pasifika People in New Zealand. Manukau: The Salvation Army Social Policy and Parliamentary Unit.

Waiapu Anglican Social Services (2010). Waiapu families in debt. Retrieved on July 31, 2014. http://www.waiapuanglicansocialservices.org.nz/userfiles/file/ Debtstories.pdf.

Walker, C. (2013). Manufacturing the right way to be in debt: Can psychologists explore the debt industry? The Austrialian Community Psychologist, 25(1): 49-59. 